\title{
Front Matter: Volume 11111
}

, "Front Matter: Volume 11111," Proc. SPIE 11111, X-Ray Lasers and Coherent X-Ray Sources: Development and Applications XIII, 1111101 (3 October 2019); doi: 10.1117/12.2551767

EDent: SPIE Optical Engineering + Applications, 2019, San Diego, California, SPIE. United States 


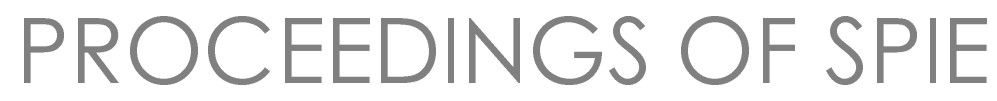

\section{$X$-Ray Lasers and Coherent X-Ray Sources: Development and Applications XIII}

Annie Klisnick

Carmen S. Menoni

Editors

12-13 August 2019

San Diego, California, United States

Sponsored and Published by

SPIE

Volume 11111 
The papers in this volume were part of the technical conference cited on the cover and title page. Papers were selected and subject to review by the editors and conference program committee. Some conference presentations may not be available for publication. Additional papers and presentation recordings may be available online in the SPIE Digital Library at SPIEDigitalLibrary.org.

The papers reflect the work and thoughts of the authors and are published herein as submitted. The publisher is not responsible for the validity of the information or for any outcomes resulting from reliance thereon.

Please use the following format to cite material from these proceedings:

Author(s), "Title of Paper," in X-Ray Lasers and Coherent X-Ray Sources: Development and Applications XIII, edited by Annie Klisnick, Carmen S. Menoni, Proceedings of SPIE Vol. 11111 (SPIE, Bellingham, WA, 2019) Seven-digit Article CID Number.

ISSN: 0277-786X

ISSN: 1996-756X (electronic)

ISBN: 9781510629158

ISBN: 9781510629165 (electronic)

Published by

SPIE

P.O. Box 10, Bellingham, Washington 98227-0010 USA

Telephone +1 3606763290 (Pacific Time) · Fax + 13606471445

SPIE.org

Copyright @ 2019, Society of Photo-Optical Instrumentation Engineers.

Copying of material in this book for internal or personal use, or for the internal or personal use of specific clients, beyond the fair use provisions granted by the U.S. Copyright Law is authorized by SPIE subject to payment of copying fees. The Transactional Reporting Service base fee for this volume is $\$ 21.00$ per article (or portion thereof), which should be paid directly to the Copyright Clearance Center (CCC), 222 Rosewood Drive, Danvers, MA 01923. Payment may also be made electronically through CCC Online at copyright.com. Other copying for republication, resale, advertising or promotion, or any form of systematic or multiple reproduction of any material in this book is prohibited except with permission in writing from the publisher. The CCC fee code is 0277$786 \times / 19 / \$ 21.00$.

Printed in the United States of America by Curran Associates, Inc., under license from SPIE.

Publication of record for individual papers is online in the SPIE Digital Library.

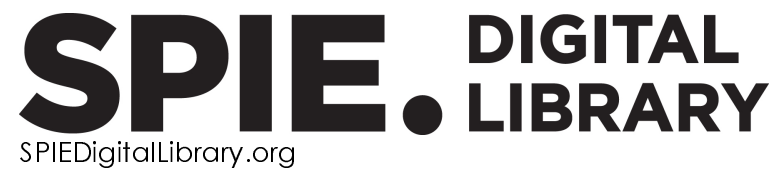

Paper Numbering: Proceedings of SPIE follow an e-First publication model. A unique citation identifier (CID) number is assigned to each article at the time of publication. Utilization of CIDs allows articles to be fully citable as soon as they are published online, and connects the same identifier to all online and print versions of the publication. SPIE uses a seven-digit CID article numbering system structured as follows:

- The first five digits correspond to the SPIE volume number.

- The last two digits indicate publication order within the volume using a Base 36 numbering system employing both numerals and letters. These two-number sets start with 00, 01, 02, 03, 04, 05, 06, 07, 08, 09, OA, OB ... 0Z, followed by 10-1Z, 20-2Z, etc. The CID Number appears on each page of the manuscript. 


\section{Contents}

$\begin{array}{ll}\vee & \text { Authors } \\ \text { vii } & \text { Conference Committee }\end{array}$

X-RAY LASERS

1111103 2D and 3D modelling of plasma amplifiers of UV, XUV, and soft $x$-rays [ $1111111-2]$

1111105 Enhanced fluorescence from $\mathrm{x}$-ray line coincidence pumping of $\mathrm{K}$-pumped $\mathrm{Cl}$ and Mg-pumped Ge plasmas (Invited Paper) [1 111111 l-4]

INTERACTION WITH SOLID MATTER AND SURFACES

$1111106 \quad$ Extreme ultraviolet laser ablation of solid targets (Invited Paper) [1 111111 -5]

1111107 Rapid 3D chemical visualization with tabletop XUV laser mass spectrometry [1 $11111-6]$

X-RAY OPTICS, IMAGING, AND METROLOGY

11111 OF Lab-scale soft $x$-ray ptychography: advanced nanoscale imaging and beam diagnostics (Invited Paper) [1 111111 l-14]

$11111 \mathrm{OH} \quad$ Beam conditioning CRL transfocator optics at the MID instrument of the European XFEL [111111-16]

LASER-DRIVEN X-RAY SOURCES AND USER FACILITIES

1111101 Progress on laser-driven x-ray sources at ELI Beamlines (Invited Paper) [1 $11111-17$ ] 
Proc. of SPIE Vol. 11111 1111101-4

Downloaded From: https://www.spiedigitallibrary.org/conference-proceedings-of-spie on 26 Apr 2023 Terms of Use: https://www.spiedigitallibrary.org/terms-of-use 


\title{
Authors
}

Numbers in the index correspond to the last two digits of the seven-digit citation identifier (CID) article numbering system used in Proceedings of SPIE. The first five digits reflect the volume number. Base 36 numbering is employed for the last two digits and indicates the order of articles within the volume. Numbers start with $00,01,02,03,04,05,06,07,08,09,0 A, 0 B \ldots .0 Z$, followed by 10-12, 20-2Z, etc.

\author{
Albrecht, Martin, 01 \\ Álvarez, Jorge, 03 \\ Andreasson, Jakob, 01 \\ Antipenkov, Roman, 01 \\ Appel, Karen, $\mathrm{OH}$ \\ Aslanyan, $\mathrm{V} ., 06$ \\ Batchelor, Lewis, $\mathrm{OH}$ \\ Batysta, František, Ol \\ Beiersdorfer, P., 05 \\ Bleiner, Davide, 07 \\ Boesenberg, Ulrike, $\mathrm{OH}$ \\ Boháček, Karel, Ol \\ Brown, C. R. D., 05 \\ Brown, G. V., 05 \\ Burridge, D., 05 \\ Charles, R., 05 \\ Chaulagain, Uddhab, OI \\ Cotelo, Manuel, 03 \\ Espinoza, Shirly, Ol \\ Finke, Ondřej, Ol \\ Gautier, J., OF \\ Goddet, J. -P., OF \\ Green, Jonathan T., 0l \\ GU, M. F., 05 \\ Guggenmos, A., OF \\ Hallmann, Jörg, $\mathrm{OH}$ \\ Hatfield, P., 05 \\ Helk, T., OF \\ Hell, N., 05 \\ Hill, M. P., 05 \\ Hoarty, D., 05 \\ Hobbs, L. M. R., 05 \\ Hort, Ondřej, Ol \\ Jurkovič, Matej, Ol \\ Karatodorov, Stefan, 0 I \\ $\mathrm{Kim}, \mathrm{Chan}, \mathrm{OH}$ \\ Kleineberg, U., OF \\ Klimešová, Eva, Ol \\ Kolzová, Michaela, ol \\ Korn, Georg, Ol \\ Krikunova, Maria, 0 \\ Lamač, Marcel, Ol \\ Lera, Roberto, OI \\ Lobato, Iker, $\mathrm{OH}$ \\ Lolley, J., 06 \\ London, R. A., 05 \\ Lu, Wei, $\mathrm{OH}$ \\ Madsen, Anders, $\mathrm{OH}$ \\ Mai, Dong-Du, ol
}

\author{
Mammen, Christian, $\mathrm{OH}$ \\ Martínez, Pablo, 03 \\ Menoni, Carmen S., 06, 07 \\ Möller, Johannes, $\mathrm{OH}$ \\ Nejdl, Jaroslav, Ol \\ Nilsen, Joseph, 05 \\ Novák, Jakub, 01 \\ Oliva, Eduardo, 03, OF \\ Panchenko, D., 05 \\ Rebarz, Mateusz, Ol \\ Richter, Steffen, 01 \\ Rocca, Jorge J., 06, 07 \\ Rose, S., 05 \\ Rossall, A. K, 06 \\ Roth, Thomas, $\mathrm{OH}$ \\ Rush, Lydia A., 07 \\ Samoylova, Liubov, $\mathrm{OH}$ \\ Saunders, A. M., 05 \\ Scholz, Markus, $\mathrm{OH}$ \\ Scott, H. A., 05 \\ Sebban, S., OF \\ Shayduk, Roman, $\mathrm{OH}$ \\ Solis-Meza, E., 06 \\ Spielmann, C., OF \\ Stiel, H., OF \\ Sukharnikov, Konstantin, $\mathrm{OH}$ \\ Tallents, G. J., 06 \\ Tissandier, F., OF \\ Tuitje, F., OF \\ Vančura, Jakub, 01 \\ Velarde, Pedro, 03 \\ Wagenaars, E., 06 \\ West, A., 06 \\ Wilson, L., 05 \\ Wilson, S. A., 06 \\ Zozulya, Alexey, $\mathrm{OH}$ \\ Zürch, M., OF
}


Proc. of SPIE Vol. 11111 1111101-6

Downloaded From: https://www.spiedigitallibrary.org/conference-proceedings-of-spie on 26 Apr 2023 Terms of Use: https://www.spiedigitallibrary.org/terms-of-use 


\title{
Conference Committee
}

\author{
Program Track Chairs
}

Ali M. Khounsary, Illinois Institute of Technology (United States)

Ralph B. James, Savannah River National Laboratory (United States)

Conference Chairs

Annie Klisnick, Institut des Sciences Moléculaires d'Orsay (France)

Carmen S. Menoni, Colorado State University (United States)

Conference Program Committee

Jens Biegert, ICFO - Institut de Ciències Fotòniques (Spain)

Hiroyuki Daido, Japan Atomic Energy Agency (Japan)

Sylvie Jacquemot, Laboratoire pour I'Utilisation des Lasers Intenses

(France)

Do-Kyeong Ko, Gwangju Institute of Science and Technology

(Korea, Republic of)

Michaela Kozlova, Institute of Physics of the CAS, v.v.i.

(Czech Republic)

Joseph Nilsen, Lawrence Livermore National Laboratory (United States)

Tenio Popmintchev, University of California, San Diego (United States)

Jorge J. Rocca, Colorado State University (United States)

Regina Soufli, Lawrence Livermore National Laboratory (United States)

Szymon Suckewer, Princeton University (United States)

Gregory J. Tallents, The University of York (United Kingdom)

Alexander Vladimirovich Vinogradov, P. N. Lebedev Physical Institute of the RAS (Russian Federation)

Marco Zangrando, Elettra-Sincrotrone Trieste S.C.p.A. (Italy)

Session Chairs

1 X-Ray Lasers

Annie Klisnick, Institut des Sciences Moléculaires d'Orsay (France)

2 Interaction with Solid Matter and Surfaces

Joseph Nilsen, Lawrence Livermore National Laboratory

(United States) 
3 EUV/ X-Ray Sources and Applications I

Sylvie Jacquemot, Laboratoire pour l'Utilisation des Lasers Intenses (France)

$4 \quad$ X-Ray Optics, Imaging, and Metrology

Jorge J. Rocca, Colorado State University (United States)

5 Laser-Driven X-Ray Sources and User Facilities

Annie Klisnick, Institut des Sciences Moléculaires d'Orsay (France)

Carmen S. Menoni, Colorado State University (United States)

6 EUV/ X-Ray Sources and Applications II

Gregory J. Tallents, University of York (United Kingdom) 